Table 1

\begin{tabular}{|c|c|c|c|c|}
\hline Strain & \multicolumn{2}{|c|}{$\begin{array}{l}\text { Duration } \\
\text { of growth } \\
\left(25^{\circ}\right) \text { (hr.) }\end{array}$} & $\begin{array}{l}0.002 M \\
\text { glutamate } \\
\text { added to } \\
\text { minimal } \\
\text { medium }\end{array}$ & $\begin{array}{l}\text { Specific glutamic } \\
\text { dehydrogenase } \\
\text { activity } \\
\text { (units/mgm. } \\
\text { protein) }\end{array}$ \\
\hline $\begin{array}{l}\text { Pseudowild from } \\
a m^{32} \times a m^{47}\end{array}$ & & 48 & - & 60 \\
\hline $\begin{array}{l}a m \text { isolates from } \\
\text { pseudowild }\end{array}$ & $\begin{array}{l}1 \\
1 \\
2 \\
2 \\
3 \\
3 \\
4 \\
4\end{array}$ & $\begin{array}{l}64 \\
48 \\
88 \\
48 \\
64 \\
48 \\
88 \\
48\end{array}$ & 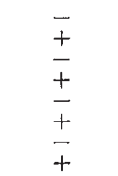 & $\begin{array}{ll}0 & (<3) \\
0 & (<0 \cdot 2) \\
0 & (<0 \cdot 6) \\
0 & (<0 \cdot 4) \\
0 & (<2) \\
0 & (<2) \\
0 & (<1) \\
0 & (<0 \cdot 7)\end{array}$ \\
\hline Heterocaryons & $\begin{array}{l}(1+4) \\
(2+3) \\
(3+4)\end{array}$ & $\begin{array}{l}64 \\
64 \\
64\end{array}$ & $\begin{array}{l}- \\
-\end{array}$ & $\begin{array}{l}75 \\
82 \\
84\end{array}$ \\
\hline $\begin{array}{l}\text { Wild type (St. } \\
\text { Lawrence } A \text { ) }\end{array}$ & & 48 & - & $>270$ \\
\hline
\end{tabular}

For experimental details, see ref. 6 .

by J. A. P.) occur with a frequency of about 0.05 per cent in $a m^{32} \times a m^{47}$ crosses, though not in $a m^{82} \times$ $a m^{32}$ or in $a m^{47} \times a m^{47}$ crosses. Cultures grown from these semi-wild ascospores grew poorly on minimal medium in comparison with wild type, were strongly stimulated by added alanine, and behaved genetically as pseudowilds, that is, strains containing complementary homologous mutant chromosomes originally included in the same ascospore nucleus and later becoming segregated into different nuclei.

Eight am strains were isolated from single conidia from a pseudowild culture. In order to reconstitute heterocaryons, thick mixed suspensions of conidia from pairs of these am isolates were spotted on to sorbose agar, and, after incubation, pieces of the resulting pellets of growth were isolated. The eight am isolates fell into two groups of four, presumably corresponding to $\mathrm{am}^{32}$ and $a m^{47}$ respectively. Pairings within each group gave ordinary am cultures, while all pairings involving one isolate from each group gave cultures resembling the original pseudowild culture in growth properties. These reconstituted heterocaryons were thereafter maintained on minimal medium. Table 1 shows the results of enzyme assays on extracts of pseudowild type, of the homocaryotic am strains derived from it, and of heterocaryons produced from them. The am strains were grown in minimal medium as well as in medium supplemented with glutamate; sufficient growth can be obtained in minimal medium in the times indicated if very large inocula are used.

It is clear that $a m^{32}+a m^{47}$ heterocaryons are able to produce glutamic dehydrogenase, though at a level considerably less than the wild type, and that it makes little difference whether the heterocaryons originate as pseudowilds or by vegetative hyphal fusion.

These results might be readily explained if 'glutamic dehydrogenase' of Neurospora were really two enzymes, acting in sequence. This seems unlikely on grounds of comparative biochemistry, and the possibility that $\mathrm{am}^{32}$ can form one enzyme, and $\mathrm{am}^{47}$ a second, complementary, enzyme, appears to be virtually ruled out by experiments in which we have failed to detect activity either in mixtures of $\mathrm{am}^{33}$ and $a m^{47}$ extracts or in extracts of mixtures of $a m^{32}$ and $a m^{47}$ mycelium.

Assuming that glutamic dehydrogenase is a single enzyme, two main interpretations of the results seem possible. It may be supposed that the synthesis of the enzyme includes two steps mediated by two distinct nuclear products. If this is the case, the close proximity of $a m^{32}$ and $a m^{47}$ seems in need of explanation. Alternatively, one may imagine that the wild-type am locus acts as a unit in producing a single component of the enzyme-forming system, and that this component can be partially reconstituted in the cytoplasm of the heterocaryon from two different defective nuclear products.

Department of Geneties,

University of Leicester.

Department of Genetics, J. R. S. FInOHAM

University of Sheffield. Jan. 10.

${ }^{1}$ Fincham, J. R. S., J. Biol. Chem., 182, 61 (1950).

2 Fincham, J. R. S., J. Gen. Microbiol., 11, 236 (1954).

3 Mitchell, M. B., Proc. U.S. Nat. Acad. Sci, 41, 215 (1955).

"Pittenger, T. H., Genetics, 38, 326 (1954).

Atwood, K. C., and Pittenger, T. H., Amer. J. Bot., 42, 496 (1955).

'Fincham, J. R. S., Biochem. $J$. (in the press).

\section{Deposition of Sulphur from Hydrogen Sulphide by Bacteria and Yeast}

IT has recently been shown ${ }^{1}$ that Sphaerotilus natans, when grown in 0.1 per cent peptone and afterwards exposed to an atmosphere of hydrogen sulphide, deposits sulphur intracellularly. Under phase contrast, there was a suggestion that the oxida. tion was associated with distinct granules within the cells. It has since been shown that these granules have properties attributed to mitochondria. Acting on the hypothesis that any large cell with well-defined granules would deposit sulphur intracellularly under similar conditions, several yeasts and one unidentified species of the fungus Alternaria were similarly treated.

Pellicle-fornaing yeasts, including Pichia membranefaciens, showed quite rapid oxidation of the hydrogen sulphide, the intracellular deposition of sulphur being associated again with granules giving reactions attributed to mitochondria. Not all granules had the same activity. The culture of Alternaria sp. also showed active oxidation of the hydrogen sulphide but has not yet been more critically examined.

The activity of yeasts and Sphaerotilus natans is increased by aeration of the cultures prior to exposure. Prolonged gassing with nitrogen inhibits the reaction.

In aged yeast cultures, considerable quantities of globular sulphur appear outside the cells. Where clusters of the globules have been extracted with pyridine, clusters of granules having an appearance similar to those within the cells are left.

Work is proceeding in an attempt to establish whether granules isolated from the cells are in fact mitochondria within the present meaning of the term, and whether the isolated granules are capable of oxidizing hydrogen sulphide.

\section{B. D. Skerman \\ GaIina DementJev \\ G. W. SKYRING}

Department of Bacteriology,

University of Queensland, Brisbane. Jan. 14.

${ }^{1}$ Skerman, V. B. D., Dementjev, Galina, and Carey, Barbara M., $J$. Bact. (in the press). 